\title{
Wśród zagranicznych książek
}

\author{
Jacek Wojciechowski
}

Przeciętna jakość publikacji informatologicznych oraz bibliotekoznawczych nie jest może wygórowana, ale też na ogół nie sprawia wrażenia nadmiernie miałkiej. Jakkolwiek trochę irytuje i nuży tą nijaką przeciętnością, kiedy przegląda się je w większych ilościach. Dlatego dużą przyjemność sprawia każda napotkana refleksja, która wyrasta ponad przeciętność oraz odbiega od sztampy. Chociaż mówiąc bardziej szczerze: prawie każda. Bo oto z niemałym zdziwieniem uświadamiam sobie, że jednak nie zawsze tak jest.

Czasem mianowicie trafiają się wypowiedzi perfekcyjnie sformułowane, wysoce erudycyjne i lekturowo poruszające, które mimo to bardziej niźli satysfakcję, wzbudzają niepokój. Pierwsze wrażenie może być świetne, ale z czasem pojawia się myśl, że jednak zręcznym argumentom brakuje (to w tych dyscyplinach reguła) twardej dokumentacji empirycznej i wszystko opiera się na spekulacjach. Które trzeba zatem poddawać krytycznej weryfikacji.

Lecz jak to zrobić, jeżeli są błyskotliwe, autor zaś nad czytającym zdecydowanie góruje merytorycznie oraz intelektualnie? A taki właśnie mam kłopot z pierwszą wśród sygnalizowanych tu książek. I w rezultacie, z symbolicznej oceny „gwiazdkowej” usunąłem gwiazdkę szóstą, która zapowiadałaby rewelację. Dla bezpieczeństwa oraz przez zakłopotanie.

\section{Infozofia dla inforgsów [*******;}

Luciano Floridi (2014). The 4th revolution. How the infosphere is reshaping human reality. Oxford: Oxford University Press, pp. 248. ISBN 978-0-19-960672-6

Luciano Floridi jest profesorem uniwersytetu w Oxfordzie, gdzie zajmuje się filozofią i etyką informacji, czyli infozofią. Jego nowa książka traktuje o relacjach między środowiskiem informacyjnym a środowiskiem społecznym - na tyle bliskich, że zahaczających o tożsamość, ale jednak nie do końca (autor uwielbia doprowadzanie argumentacji do kresu, żeby nagle zrobić unik) - z rzadko spotykaną erudycją, lekkością oraz imponującą logiką wywodów. To jest rozprawa świetnie napisana, tak znakomita i niebezpiecznie mądra, że potrafi wmówić nawet to, co jest zaledwie cienką hipotezą wstępną, ale tę cienkość trudno zauważyć,

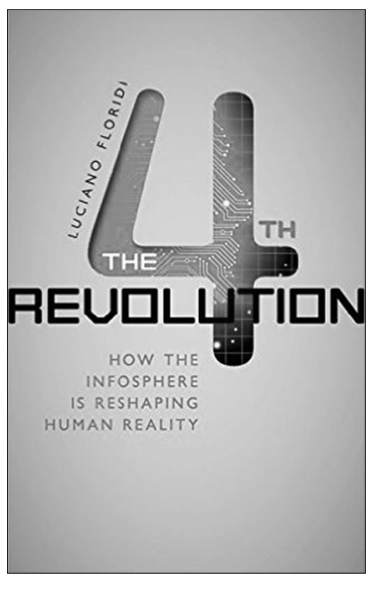
bo zawiera się również w licznych metaforach. Trzeba więc w czytaniu zachować szczególną czujność (co udaje się nie zawsze), natomiast samą lekturę dobrze byłoby uznać za powinność każdego, kto naukowo para się informacją.

Charakteryzując społeczną komunikację - którą utożsamia z informacyjną (a ja nie i stąd rozbieżność) - Floridi odwołuje się do „prawa” Moore’a, które insynuuje, że liczba tranzystorów w układach scalonych podwaja się co dwa lata, zaś koszt mocy iPadów (ale to już nie według Moore’a) zmniejsza się w proporcji odwrotnej. I wprawdzie to jest raczej metafora niż prawo, jednak autor uważa na tej podstawie, że komunikacja globalna będzie w większości elektroniczna. Może będzie, a może nie 
będzie. Oraz jest pytanie: kiedy? Na razie bowiem większość ludności świata o żadnej elektronice nawet nie słyszała, więc to jest (jeśli jest) przyszłość bardzo odległa i na pewno nie powszechna. Floridi sam przecież pisze o informacyjnych pariasach...

Na razie zwraca zaś uwagę na gigantyczny nadmiar danych - w formule Big Data - bo ich produkcja znacznie przewyższa możliwości odbioru, a także przechowywania i dlatego wymienia się je lub usuwa co 2-5 lat. Nawiasem mówiąc, taki też jest istotny dylemat bibliotek: usuwać kolejne wersje dokumentów elektronicznych, czy jednak nie. Autor uważa, że chmura jest teraz najlepszą formą przechowywania długotrwałego i kompletniejszego, jednak dowodów nie przedkłada. A samą mnogość danych zbywa supozycją, że przecież nie wszystkie muszą być dla każdego. Otóż to nie jest argumentacja przyzwoita.

Jednak spojrzenie autorskie koncentruje się głównie na przemianach w układzie komunikowania, od relacji człowiek>technologia>natura (chyba błąd! - najprzód było: człowiek>człowiek i człowiek>natura), przez zestawienie człowiek>technologia>technologia, po współczesność technologia$>$ technologia>technologia. To znaczy, że są obecnie sytuacje, kiedy urządzenia współpracują tylko ze sobą, a człowiek jest na zewnątrz układu i kontaktuje się przez interfejs. Jest więc beneficjentem, konsumentem, ale źle, jeżeli biernym.

Z drugiej strony - widzę tu sprzeczność rozumowania - człowiek jest zlepiony z infosferą i nie może do niej wejść ani z niej wyjść. Stała się bowiem synonimem (surogatem) realności. Nastąpiło tej realności odfizycznienie i zamiast podziału na życie offline oraz w przestrzeni online, ma miejsce zbitka onlife, gdzie człowiek jest odtąd inforgsem. Oto nowe wyznanie wiary i świeża koncepcja świata, mianowicie MATERIALIZM WIRTUALNY oraz paninformacjonizm: wszystko jest informacją.

Sprawnie to opowiedziane, ale bez dowodów (czysta spekulacja) i nie bez wzajemnych rozbieżności. Rzecz w tym, że struktury informacyjne coraz silniej OTACZAJĄ ludzi (daleko nie wszystkich!), lecz utożsamienie ich z całą realnością to złudzenie. Jakiemu ulegają dziewczyny, głośno perorujące przez komórki o sprawach intymnych w zatłoczonym autobusie: obecność online to iluzja, zaś sąsiedztwo pasażerów to twardy konkret realny. Jeżeli więc w rozważaniach ta dysfunkcja będzie zamazana, to dojdzie się do wniosków fascynujących, lecz z gruntu fałszywych.

Floridi ma własne koncepcje społecznego rozwoju i nadaje im wysoką rangę. Sugeruje mianowicie, że najprzód Kopernik wyłuskał człowieka z centrum wszechświata, potem Darwin przez teorię ewolucji przesunął na inne miejsce poza centrum wszechżycia, zaś Freud sygnalizując podświadomość, podważył teorię Kartezjusza o ludzkim myśleniu i o introspekcji jako o podstawie egzystencji. Z kolei Thomas Hobbes uznał wprawdzie, że ludzkie myślenie to obliczanie - więc byłby to może „jakiś” nawrót prokartezjański - ale ostatecznie Alan Turing wypchnął nas poza świat cybernetyczny, jednak z zachowaniem przylepialności.

Autorska sugestia brzmi tak, że pamięć (w sensie treści) jest przekazywana maszynom w trybie outsourcingu (dobrze byłoby zaznaczyć, że jednak nie w całości), lecz mimo to urządzenia techniczne zmieniają nie tyle samego człowieka, co otoczenie, w którym przychodzi mu żyć. I w takim przylepialnym, symbiotycznym sensie, trzeba postrzegać inforgsów, czyli społeczne organizmy informacyjne.

Nie powiem, żeby to rozumowanie było w pełni klarowne i nadmiernie obfitowało w dowody, ale frapujące jest na pewno. Trochę więcej światła rzuca zaś wywód na temat współczesnej świadomości samego siebie, która (znowu trzeba dodać: częściowo) generuje się także w digitalnej sieci. Jest tam mianowicie cyfrowy, zatem nie własny lecz cudzy, wizerunek każdego z nas, utkany po części z tego, co na swój temat każdy naklikał świadomie, lecz również z cudzych opinii o nas w Internecie, a nade wszystko z pozaświadomej rejestracji (w systemie) wszystkich naszych zachowań sieciowych. I rzeczywiście: trudno wyzwolić się z tych wizerunkowych wpływów, a dla użytkowników sieci nie ma żadnego sposobu, żeby je uciąć.

To z kolei ma odniesienie do problemu prywatności informacyjnej - bo jest i taka, obok prywatności fizycznej, mentalnej oraz decyzyjnej. To LUKA w informacji o SOBIE, dla INNYCH. Otóż sieć tę lukę redukuje, na różne sposoby upublicznia prywatne informacje, mnoży oraz kumuluje, ale inaczej, 
w innej skali niż to miało miejsce dotychczas, w tradycyjnym łamaniu konfidencjonalności - choćby dlatego, że sieciowe środowiska informacyjne nie mają fizycznych usytuowań ani granic. I wprawdzie autor zmierza ku temu, że konstruowane narzędzia mogą zarówno naruszać prywatność, jak też ją chronić, jeśli są stosownie używane, ale to wymaga jakiegoś zdystansowania się od nich. Tymczasem cały wywód w tej książce zmierza raczej (powtórzę) ku nastawieniom symbiotycznym.

Choć nie zawsze konsekwentnie. Szczególnie przewrotnie prezentują się bowiem wywody kolejne: na temat inteligencji.

Otóż Floridi tak zwaną inteligencję urządzeń zbywa uwagą, że zależy od tego, jak się ich używa, a zatem nie bierze się z nich samych. Jego zdaniem, komputery radzą sobie tylko z danymi surowymi, są więc czysto syntaktycznie, a nie semantycznie: INTERPRETACJA znaczeń to już nie ich działka. Owszem, wpisują (i opisują?) świat w logiczno-matematyczny kod, ale to jest operacja mechaniczna, nawet jeżeli skomplikowana. Temu rozumowaniu trudno coś zarzucić, poza jednym: uważam że nie do końca odpowiada opiniom, wcześniej w tej książce wyrażonym. Ale może to tylko taki mój niedowład intelektualny, albo nadwrażliwość.

Jakkolwiek autor trochę do tego zachęca. Choćby zadając pytanie, czy w systemach informacyjnych zawierają się jakieś UKRYTE informacje, które ogłupiają. Przy założeniu semantycznej jednoznaczności, zapewne nie, ale sam przecież wspomina o interpretacji, czyli znaczeniowej subiektywizacji informacji, a to oznacza, że efekty tego samego procesu informacyjnego mogą być odmienne. Co jednego ogłupia, to drugiego nie - żeby już nie odwoływać się do zbiorowości pozasieciowych.

W innym miejscu autor powiada, że nie istnieją technologie, które byłyby poza zasięgiem działań i zmian prewencyjnych, a więc decyzyjnych. Dla pewności przywołuje test Turinga, który (przypomnę w uproszczeniu) polegał na rozróżnieniu między interlokucją z człowiekiem oraz z komputerem. To argument uspokajający i mitygujący fantazje, rodem z science fiction. Dopowiem jednak, że niedawno doniesiono o eksperymencie - pierwszym, w którym takie rozróżnienie nie nastąpiło.

W ostatecznej konkluzji Floridi sugeruje, że rozwój technologii jest jak gambit w szachach. Kosztem drobnych, ewentualnie uciążliwych zmian (stąd obawy), przynosi olbrzymie pożytki (stąd postulowany entuzjazm). Trzeba więc akceptować CZWARTĄ REWOLUCJĘ, która wytworzy nowe technologie i nowe środowisko informacyjne, a w konsekwencji: nowe otoczenie fizyczne oraz intelektualne. W porządku. No bo czy mamy inne wyjście?

Chyba że... nie wszystko, co autor przedstawił w swoim świetnym narracyjnie wywodzie, ma lub będzie miało pokrycie w realnej rzeczywistości - którą dla bezpieczeństwa wolałbym odróżniać od wirtualnej. Bo spekulacji jest w tej książce dużo, nie zawsze tak właśnie (jako hipotezy) sygnalizowanych. Czytać więc trzeba ostrożnie, na tyle krytycznie, na ile się da. Natomiast z ogromną satysfakcją i przyjemnością.

\section{Z Indii [*****]}

Ajay Pratap Singh, Mayank Yuvaraj (2013). Information, communication and society. New Delhi: Ess Ess Publications, pp. 203. ISBN 978-81-7000-693-0

Już zdarzało mi się sygnalizować publikacje z Indii. Bywały różne: ciekawe, przeciętne, a czasami także beznadziejne. Jak wszędzie. W dobie globalizacji to nic niezwykłego, zwłaszcza kiedy jakaś krajowa nauka bazuje na języku angielskim.

Tym razem trafiłem na książkę naprawdę interesującą. Jej głównym autorem jest prof. Ajay Singh z Benares University w mieście Varanasi, a współautorem - asystent Mayank Yuvaraj. To jest podręcznikowa monografia z zakresu komunikacji oraz informacji, z tej racji definiująca

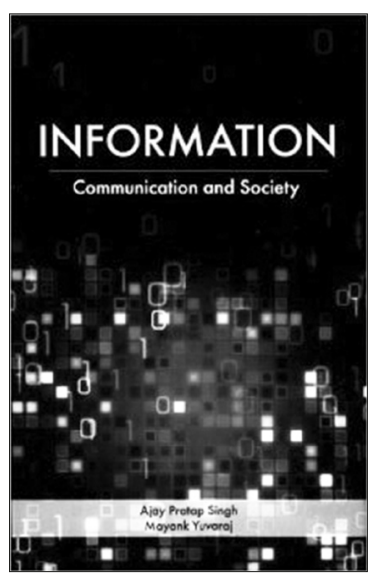


rozmaite pojęcia oraz zjawiska, na ogół znane, lecz czyni to trochę inaczej, aniżeli w praktyce euro-amerykańskiej. No bo jednak co Azja, to Azja. Zreferowano tam niby to samo, jednak nie całkiem tak samo i myślę, że porównanie może być produktywne.

Zgodnie z zasadami, eksplikacja zaczyna się od „abece”, czyli od zdefiniowania danych. No więc dane - jak tam napisano - to surowy materiał do procesualizacji, informacja zaś to ogół opracowanych danych. Z kolei wiedza powstaje przez aplikację danych oraz informacji, z koniecznością zrozumienia, podczas kiedy mądrość bierze się ze zrozumienia ZWALORYZOWANEGO.

Czy coś w tym nie tak? Proszę uprzejmie: są też objaśnienia inne. Mianowicie takie, że dane to symbole, zaś informacje powstają przez zrelatywizowanie danych z rzeczywistością. Natomiast (wtedy) na mądrość składają się informacje przetworzone, zrozumiane oraz wykorzystywane.

A jeżeli to jeszcze nie wystarczy (dla mnie irytujące jest - znowu - utożsamienie CAŁEJ komunikacji z informacją), to są w książce dalsze charakterystyki, lecz już wyłącznie samej informacji. No więc informacja to: każdy sygnał przyjęty i zrozumiany - albo znaczenie wspólne dla różnych sposobów wyrażania - lub taka sama w grupie interpretacja znaków - bądź abstrakt reprezentujący obiekt - względnie zmiana stanu świadomości po odbiorze sygnału. Proszę sobie wybrać, co komu odpowiada, chociaż osobiście preferuję jeszcze jeden wariant, wskazany w tekście, mianowicie zdolność sygnalizowania treści prawdziwych.

Mniej odkrywcza jest natomiast charakterystyka procesów KOMUNIKACJI - po prostu jako transmisji lub wymiany treści - podzielonych na nieformalne oraz formalne, czyli ze sformalizowanym i ujawnionym autorstwem; z tego podziału nie wynika nic. Tak jak i z rejestru możliwych relacji komunikacyjnych: jeden do jednego, jeden do wielu, wielu do wielu. Zresztą oczywiście zabrakło wielu do wielu, a to wszak istota komunikacji sieciowej.

Autorzy spisali oraz detalizowali również bariery w komunikacji. Fizyczne (dystans, nadmiar, zakłócenia), semantyczne (niezrozumienie), organizacyjne (brak dostępu, inna niemożność odbioru), emocjonalne (brak zaufania, nieakceptowanie nadawcy albo treści), oraz techniczne i finansowe. Jest więc co przełamywać, ale niekoniecznie wiadomo jak.

Naukę o informacji określono w książce jako interdyscyplinarną i przypisano do nauk społecznych. Zdaniem autorów, zajmuje się głównie cechami informacji oraz jej funkcjonowaniem. Następnie zostało zreferowane całe naręcze rozmaitych ujęć, które trudno tu zestawiać. A poza tym jest też spis relacji zewnętrznych do: technologii, matematyki, wiedzy o komunikacji, językoznawstwa, teorii edukacji oraz do kognitywistyki - której nie wiadomo czemu przypisano sprzeczność z bibliotekoznawstwem. A znów bibliotekoznawstwo, chociaż powiązane z nauką o informacji, odróżnia się od niej (tak twierdzą Singh i Yuvaraj) nastawieniem na usługi. Nie da się ukryć, że bardzo to mętne.

Jest też dłuższy opis metodologii informatologicznej, ale moim zdaniem kiepski, bo chaotyczny: wszystko zostało dokładnie poplątane - metody z technikami i teorie z hipotezami. Oraz nie podoba mi się przydługa charakterystyka bibliometrii, infometrii, jak też scjentometrii, nie dość że naiwna, to jeszcze komentująca bezkrytycznie rozmaite „prawa” Lotki, Bradforda, Zipfa i innych. Trzeba wreszcie powiedzieć jasno, że to nie są żadne prawa, tylko metafory (Lotka był przed stu laty chemikiem) i nie można ich traktować dosłownie.

Są w książce odniesienia do pojęcia społeczeństwa informacyjnego - chociaż w Indiach zasięg Internetu nie przekracza 5\% populacji - które (pojęcie) funkcjonuje od 1960 r. i jest dość kontrowersyjne. Zdaniem autorów, sugeruje ono ogólne organizowanie się społeczeństw wokół wiedzy oraz szerokie uznanie informacji jako głównej (może lepiej: ważnej?) wartości społecznej. Myślę, że to jest opinia rozsądna. Zawarta ponadto w spostrzeżeniu, że erupcja informacji nie tylko rozwija dostęp do niej, ale też różnicuje: ma miejsce stratyfikacja i nie jest to zjawisko korzystne.

Obecna rzeczywistość informacyjna generuje potrzebę nowych specjalności zawodowych pracowników informacji. Autorzy wyliczają takie oto: twórca informacji - znawca informacji (doradca?) konsolidator informacji - analizator informacji - oferent informacji (infobroker). Nazwy są czytelne, a czy taki podział ma sens, trudno mi ocenić. Każdy ma prawo do własnego na ten temat zdania. 
Większe kontrowersje może wywołać natomiast retrospektywny rzut oka na rozwój teorii oraz samej profesji bibliotekarsko-informacyjnej. Teoria miałaby kształtować się mianowicie tak - dominacja: ekonomii bibliotecznej od 1876 r., bibliotekoznawstwa, czyli wiedzy o bibliotekarstwie od 1900 r., bibliotekoznawstwa oraz informacji naukowej od 1950 r. i wreszcie informacji naukowej od 2000 r. Natomiast dzieje zawodu podzielono następująco: epoka praktyczna 1876-1950 r., czas budowy teorii 1950-2000 r., era digitalna od 2000 r. Można sobie dzielić oczywiście wszystko, jak kto chce, ale dlaczego i po co? Podstaw TAKIEJ etapizacji nie umiem odgadnąć, natomiast nietrudno zauważyć, że nie wynika z tego nic.

Information Literacy - pojęcie, które wprowadził Paul Zurkowski (wtedy: przewodniczący Information Industry Association) jeszcze w latach siedemdziesiątych - autorzy definiują jako umiejętność konkretyzowania własnych potrzeb informacyjnych, oraz określenia i odnalezienia odnośnych zasobów zakresowych, a także weryfikacji oraz spożytkowania. To zapewne jest do zaakceptowania. Tak jak i rejestr form wdrażania IL, na tyle długi, że nie da się go tutaj przytoczyć, lecz w zasadzie zgodny z tym, co pisuje się na ten temat standardowo.

A poza tym jest jeszcze wypowiedź o zarządzaniu wiedzą jako o odrębnej, eklektycznej dyscyplinie nauki. Od razu zresztą rzuca się w oczy niezgodność między sygnalizowanymi wcześniej definicjami wiedzy, a przyjętą tym razem - ale to jest dosyć powszechne. Mianowicie najprzód ma miejsce taka lub inna charakterystyka wstępna, a potem każdy wraca do potocznego pojmowania wiedzy jako ogólnego dorobku ludzkiej myśli.

Autorzy objaśniają zarządzanie wiedzą na kilka różnych sposobów. Jako formę kreowania informacji (?!), lub jako praktykę pozyskiwania wiedzy nowej, albo: jako taką koordynację procesów poznawczych, żeby tę nową wiedzę dodawały i kumulowały z już istniejącą. Jest też wyliczenie związanych z tym specjalności zawodowych. To zarządca wiedzy, nawigator wiedzy, specjalista (?), syntetyzator wiedzy, oraz wydawca (transmiter) wiedzy. Co referuję, lecz domyślam się, że o akceptację może być trudno.

W sumie jednak książka jest interesująca. Także dlatego, że uświadamia globalne podobieństwa. Wszędzie mianowicie uprawia się naukę o informacji w (co najmniej) zbieżny sposób - a ewentualne odmienności też mogą okazać się produktywne.

\section{Handel informacją [***]}

Michale L. Gruenberg (2014). Buying and selling information. A guide for information professionals and sales people to build mutual success. Medford: Information Today, Inc., pp. 195. ISBN 978-1-57387-478-6

A oto wypowiedź wieloletniego sprzedawcy z amerykańskiej firmy ProQuest (dostawca technologii oraz zasobów informacyjnych) na temat kontaktów handlowych z bibliotekami. To NIE JEST publikacja naukowa. Autor, magister nauk o zarządzaniu i zawodowy muzyk, ma już teraz własną firmę doradczą, ale spostrzeżenia z doświadczeń uprzednich - jako spojrzenie z drugiej strony, przez inny pryzmat kontrahencki - wydają się interesujące. A byłyby jeszcze ciekawsze, gdyby autor nie podlizywał się pracownikom informacji i bibliotekarzom,

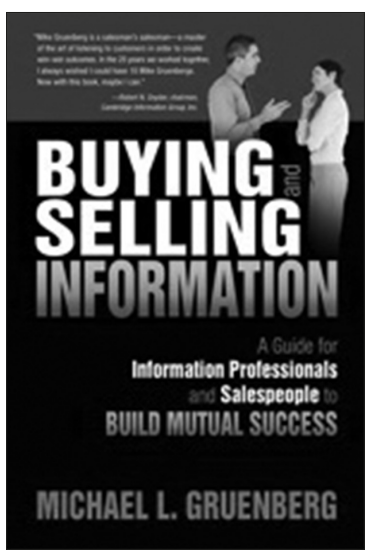
oraz mniej ostentacyjnie wyrażał zadowolenie z siebie. Chociaż bowiem satysfakcja ze swojej pracy to uczucie wspaniałe, ale najlepiej demonstrować je w sposób umiarkowany.

Gruenberg ma jednak rację sugerując, że transakcje realizują nie firmy lecz ludzie, toteż trzeba się osobowo poznać wzajemnie i budować zaufanie. Dlatego sprzedawca powinien odwiedzić bibliotekę, 
obejrzeć stanowisko pracy kontrahenta i wyciągnąć wnioski. Jeśli zauważy bałagan, to zrozumie, że klient jest niezorganizowany i realizacja sprzedaży będzie trudna. (Dla nas zaś to podpowiedź, żeby takich oferentów przyjmować w kawiarni albo w gabinecie cudzym.)

Tych wizyt i spotkań zaleca sporo. Po pierwszym telefonicznym kontakcie, wyjaśniającym z grubsza, o co chodzi, należy umówić się na spotkanie bezpośrednie, poświęcone detalom i wyjaśnieniu, czemu TA właśnie oferta jest lepsza od innych. Później trzeba będzie zaaranżować jeszcze kilka spotkań, kontynuacyjnych i poszerzających objaśnienia - z pożądaną prezentacją ofertową (wystawą, minitargami) - aż dojdzie do kontaktu finalnego. To wtedy (nie wcześniej) powinno nastąpić ostateczne określenie ceny, a także upustów i zawarowanie standardów jakościowych oraz regulacji posttransakcyjnych i ewentualne podpisanie umowy. Tak to w zasadzie powinno wyglądać, a że przeważnie wygląda inaczej, to już problem odrębny.

Autor uważa, że biblioteki dla sprzedawców technologii oraz pakietów informacji, tworzą świetny rynek zbytu, ale w zasadzie już pełny, toteż konkurencja jest silna. Poza tym biblioteki informują się wzajemnie o sprzedawcach, więc opinia jest jak ogon komety. To żadne odkrycie, ale jednak cenna (chociaż mimowolna) podpowiedź dla nas, żeby w kontaktach zachowywać się co najmniej po partnersku, a nawet wymuszać (byle rozsądnie) możliwie korzystne porozumienia. Nie jesteśmy petentami!

Stąd bierze się autorska opinia, że sprzedawca powinien bardziej słuchać niż mówić i nastawić się, że klient ma rację (to slogan) nawet wtedy, kiedy jej w istocie nie ma. Co uzupełniają rozmaite dorady szczegółowe - nawet taka, że najlepsza pora na handlowe kontakty w ciągu dnia jest między godzina dziesiątą a dwunastą. Generalnie zaś Gruenberg twierdzi, że dobry oferent powinien być również DORADCĄ klienta, tymczasem pracownicy informacji i bibliotekarze widzą w nim często przeciwnika. To źle, ale z doświadczeń własnych dopowiem, że bywają ku temu powody.

Jest też w książce kilka podpowiedzi dla pracowników informacji. Do rozmów transakcyjnych powinni oni być dobrze przygotowani - nie zaszkodzi obejrzeć wcześniej strony WWW oferenta i ułożyć sobie listę pytań - a potem powinni rozmawiać możliwie konkretnie oraz zachowywać się aktywnie. Nieraz warto też objaśnić oferentom istotę i proces funkcjonowania tego segmentu biblioteki, którego transakcja dotyczy. Jest tam też zachęta do NEGOCJOWANIA cen oraz warunków transakcji (Gruenberg zauważył, że bibliotekarze tego nie umieją), byle w zgodzie z regułami rozsądku, no bo jakiś zysk sprzedawca mieć musi. Ogólnie zaś, według autora, najlepiej współpracuje się z dobrymi zawodowcami, ponieważ doskonale wiedzą, czego chcą.

Natomiast nigdy nie można wykluczyć najrozmaitszych trudności i te trzeba pokonywać RAZEM, co właśnie ułatwia dobra atmosfera i wzajemne zaufanie, a czasami użyteczne mogą też być porady ekspertów. Do momentu sfinalizowania operacji, „karty w ręku” trzymają pracownicy informacji, potem zaś - oczywiście już nie. Ale dobrze, jeżeli kontakty są podtrzymywane, a gdyby pojawiły się niespodziewane problemy, nawet spoza gwarancyjnego pakietu, to warto je sprzedawcy zasygnalizować.

No bo w ten sposób dopełnia się wzajemna satysfakcja - ważna dla obustronnego samopoczucia oraz dla ewentualnych transakcji następnych. Nie trzeba będzie bowiem rozpoczynać wszystkiego od zera.

W czym Gruenberg ma W ZASADZIE rację, ale z jednym ważnym zastrzeżeniem: w swojej praktyce nie miał do czynienia z polskim prawem o zamówieniach publicznych. Gdyby bowiem miał, to nigdy nie napisałby takiej książki.

Nadestano: 29.10.2014. 